\title{
EDUCATIONAL AND THERAPEUTIC BENEFITS OF "CONTENT-FOCUSED ACCESSIBLE E-LEARNING MATERIAL” FOR VISUALLY IMPAIRED UNIVERSITY STUDENTS
}

\author{
Chikako Ota \\ Division of Research on Support for the Hearing and Visually Impaired, Research \\ and Support Center on Higher Education for the Hearing and Visually Impaired, \\ National University Corporation Tsukuba University of Technology (Japan)
}

\begin{abstract}
The idea of "educational therapy" is quite different in Japan compared to foreign countries, especially in the US, where educational therapy is quite advanced. Therefore, this study determines the educational therapeutic benefits of the author's "Content-Focused Accessible E-Learning Material" for English self-learning, based on the concept developed in the US, particularly focusing on visually impaired students. These students experience various difficulties in higher education, such as 1) the absence of learning materials in braille, 2) commercial unavailability of magnification-capable learning materials and digital materials, and 3) lack of text-to-speech function in many learning materials. To study whether the material had any therapeutic benefits for these students, the author obtained feedback from 33 students. The feedback was based on the following questions: (1) technical aspects: Did the material reduce/rid the load/concern they felt; and (2) mental aspects: Did the material increase the willingness/autonomy or decrease anxieties and did they feel accomplished or motivated to improve their longitudinal English self-study? The findings show that the material was beneficial to them in five ways.

In conclusion, the goal of this study was accomplished to a considerable degree; accessible learning material that enabled visually impaired students to study English efficiently was created, and the use of this material reduced students' mental burden in learning. Additionally, it is worth mentioning that students using braille and those who had no major visual difficulties commented that both could share the same learning material, enabling them to study together. Students are hoped to continue carrying out a longitudinal self-learning after graduating, as they build their careers.
\end{abstract}

Keywords: "Content-focused accessible e-learning material", educational and therapeutic benefits, visually impaired university students, English learning.

\section{Introduction}

In this article, the author uses feedback from visually impaired university students to determine the educational therapeutic effectiveness of "Content-Focused Accessible E-Learning Material." Their comments indicate that they felt they had received significant benefits from this material's existence, and that the absence of or inconvenience of using accessible learning materials had caused hardship for them.

According to previous studies, "educational therapy " conducted in Japan is defined as in-school interventions designed for mentally and physically disabled children who attend appropriate schools. The main therapy method is movement education and therapy, where teachers sing songs, encourage body movements, and draw pictures with students, along with other therapies.

In domestic studies, the keyword educational therapy does not exist. Movement education and therapy is the Japanese equivalent to the phrase educational therapy, and is the primarily teaching method for children or students in special schools in Japan. Meanwhile, the keywords "educational therapy" and "educational therapeutic" exist in many studies conducted overseas ${ }^{\mathrm{ii}}$. As it is presented in these studies, educational therapy could include many of the concepts incorporated in Japanese schools; the phrase educational therapy may simply be more common overseas, particularly in the United States. In the US, some national and private organizations offer educational therapy.

Educational therapy as it is conducted in the US is closely related to the educational therapeutic benefits found in the study of "Content-Focused Accessible E-Learning Materials" which the author created and then used with visually impaired university students. Students with visual impairment often struggle when learning English. For example, some question patterns which are typical for sighted 
students are difficult for visually impaired students to solve or even grasp. They also lack learning materials in higher education levels, such as braille versions of English exercise books. Some students also are unable to utilize technical accessibility options, such as operating a computer screen reader or braille display, especially when their visual impairment is suddenly or gradually acquired.

This article demonstrates how the author's "Content-Focused Accessible E-learning Material" creates an educational therapeutic benefits for visually impaired university students.

\section{The definition of "educational therapeutic benefits" in this study}

In this section, the author defines the educational therapeutic benefits regarding "Content-Focused Accessible E-Learning Material" based on educational therapy. As mentioned in the introduction, the US has several organizations, both national (e.g., Association of Educational Therapists ${ }^{\mathrm{iii}}$ [AET], the National Institute for Learning Development $[\mathrm{NILD}]^{\mathrm{iv}}$, etc..) and private, which offer educational therapy. AET defines educational therapy as:

What is Educational Therapy?

Educational therapy is the practice of providing personalized remedial instruction to children and adults with learning challenges, including but not limited to dyslexia, ADHD, executive functioning deficits, and language, visual and auditory processing issues. The ultimate goal of educational therapy is to foster development of self-confident, independent individuals who feel positively about themselves and their potential as lifelong learners.

Educational therapists understand the social, behavioral and emotional factors that can impact learning. They have extensive training and experience in administering academic assessments, developing intervention plans, and implementing strategies to addresses challenges with reading, writing, spelling, math organization, and study skill. [skip the rest] ${ }^{\mathrm{v}}$. (underlined by the author)

In this study, educational therapeutic benefits based on educational therapy regarding "Content-Focused Accessible E-Learning Material" is defined as follows;

1) to provide remedial instruction to visually impaired students with challenges in studying English.

2) to reduce negative emotions (e.g., wanting to avoid learning English, or experiences of anxiety, anger, frustration, etc.) due to visual impairment through studying "Content-Focused Accessible E-Learning Material."

3 ) to encourage students to raise their self-esteem regarding university performance.

4) to inspire students to be willing to be a longitudinal learner of English, depending on their career path.

5) to foster development of self-confident, independent individuals who feel positively about themselves and their potential as lifelong English learners.

In this article, these kinds of effectiveness are referred to as educational therapeutic benefits for visually impaired students that can be achieved by studying "Content-Focused Accessible E-learning Material."

\section{The common difficulties faced by visually-impaired English learners in university self-learning}

Students with visual impairment usually use assistive technology which enable them to access learning materials: braille, enlarged characters, text-to-speech function, and PC magnification, among others. However, none of these devices are perfect for all students, even those with high technical skills. For example:

\section{a) braille}

There are fewer learning materials for higher education levels. For example, learning materials for TOEIC preparation do not exist, other than a few very old versions on Sapie Library, the bibliographic database for visually impaired people which provides digital talking and braille materials. Visually impaired students have long-standing difficulties in self-learning for TOEIC.

\section{b) enlarged characters}

For students with severe low vision, using a magnifier for a long time can cause physical and mental exhaustion.

Magnification-capable learning materials and digital materials for higher education are not commercially available.

Students are required to request that self-learning materials be created.

Although several publishers produce online language learning materials, as Adobe Flash Player is used for screen transitions, it is impossible to magnify screens using screen magnification software. 
In either case, students must wait for a long time for the materials to be completed. As a result, many students are in peril of losing out on important opportunities during the period in which they are motivated and interested to learn, and need to engage in learning activities.

c) text-to-speech function

For many learning materials, the screen reader does not support the text-to-speech function.

In essence, a self-learning environment for students with visual impairment has not been fully developed. In many cases, sufficient progress cannot be made only through "technical accessibility to information". The author has therefore developed what "Content-Focused Accessible E-Learning Material," which could solve the problems often faced by visually impaired university students to a considerable degree.

\section{Educational therapeutic benefits acquired by "content-focused accessible e-learning materials" based on feedback comments from the students}

\subsection{Pedagogic dimensions of the intervention}

First, it might be inevitable for us educators to consider suitable pedagogical interventions when we efficiently manage students' feedback. According to Arimoto (2017a, 2017b), based on the ERIC database $^{\mathrm{vi}}$, there are numerous types of pedagogical interventions for an assessment system.

The following items are in the ERIC database which the author paid special attention: feedback, growth models, sustainability, needs assessment, formative evaluation, home study, instructional material evaluation, participant satisfaction, experiential learning, affective objectives, student-centered curriculum, instructional development/effectiveness/improvement/innovation, creative teaching, diagnostic teaching, educational therapy, special classes, teacher effectiveness, student development, student participation, educational needs, educational objectives, outcomes of education, student rights, evaluative thinking, active learning, discovery learning, theory of mind, and, best of all, self-efficacy, self-esteem, and so on, which are especially important factors in teaching visually impaired university students..

Among these educational items, the author paid special attention to educational therapy in this study, which leads to self-efficacy and self-esteem. To teach university students with visual impairments, special teaching methods and careful attention are critical since they have various kinds of difficulties in English learning, as mentioned above. Educational therapy is defined as "Educational practices that contribute to the treatment of students' organic or functional disorders" (e.g., remedial reading instruction that improves self-esteem).

"Content-Focused Accessible E-learning Material" has been proven to have educational therapeutic benefits from students' feedback. For this reason, educational therapy is focused on in this study.

\subsection{Feedback questions}

The author assigned 25 first-year students and 8 third-year students who were visually impaired to study "Content-Focused Accessible E-Learning Material." To study whether the material had any therapeutic benefits for these students, the author obtained feedback from the students.

Students' visual impairment is as follows (total number respectively):

blind (4 students), almost blind (3 students), severe low vision (6 students), loss of most of visual field (4 students), low vision (10 students), narrowed visual field (3 students), central scotoma (1 student), night blindness ( 3 students), and light aversion (1 student). Many cases had combined symptoms of visual impairment.

Students can also be classified into five categories as follows: users of braille (6 students), users of text-to-speech function (6 students), users with almost complete loss of visual field (4 students), other users (low vision, narrowed visual field, central scotoma, night blindness, light aversion) (18 students), users who can read printed learning material without major difficulties ( 5 students).

Feedback questions are the following;

1) Pick up one of the "content-focused accessible e-learning materials" which you think is necessary for you and study at least ten grammatical items

2) Provide feedback both on what is effective and what needs to be improved/revised

3) About this learning material 1

3.1) Provide the reason(s) why you chose the learning material(s) achievement?

3.2) Did you feel that the learning materials were effective, and did they affect your sense of

3.3) Did this material develop your autonomy and fluency for self-learning English?

4) About this learning material 2 
4.1) Has this material reduced your difficulties, anxieties etc. in self-learning English and other things? If Yes, which points were reduced, and how were they reduced?

4.2) Does this learning material reduce your difficulties, anxieties etc. in longitudinal self-learning English to the future?

5) (voluntary disclosure) impairment?

5.1) What kinds of difficulties and anxieties etc. have you ever experienced due to visual impairment?

5.2) What kinds of devices and effort have you made to accommodate your visual

5.3) Do you think special kinds of accessibility to information in English learning are required? If Yes, what type(s)?

\subsection{Findings}

The author categorized the results of the feedback into two groups: (1) technical aspects and (2) mental aspects, as follows. The findings show that the material was beneficial to students in the following ways (Table 1): 1. The students could use familiar PC environments , 2. As this material did not focus on technical accessibility, but rather more accessible "content" supported many kinds of visual impairment, it enabled students to study more efficiently, 3. They did not have to carry braille materials, 4. They could study regardless of TPO (e.g. via iPad), and, 5. Spelling mistakes while reading and writing decreased. Additionally, since the students' difficulty in learning English was mainly due to the visual impairment itself, this material reduced their anxiety. The reduced technical load (i.e. creating digital and braille data, physical and mental exhaustion caused by long use of magnifiers, lots of visual line movement) led to a feeling of accomplishment/willingness. The major concern of choosing suitable learning materials was resolved as the learning material was created by the teacher, which motivated them to study English.

Table 1. Results of the feedback (\%).

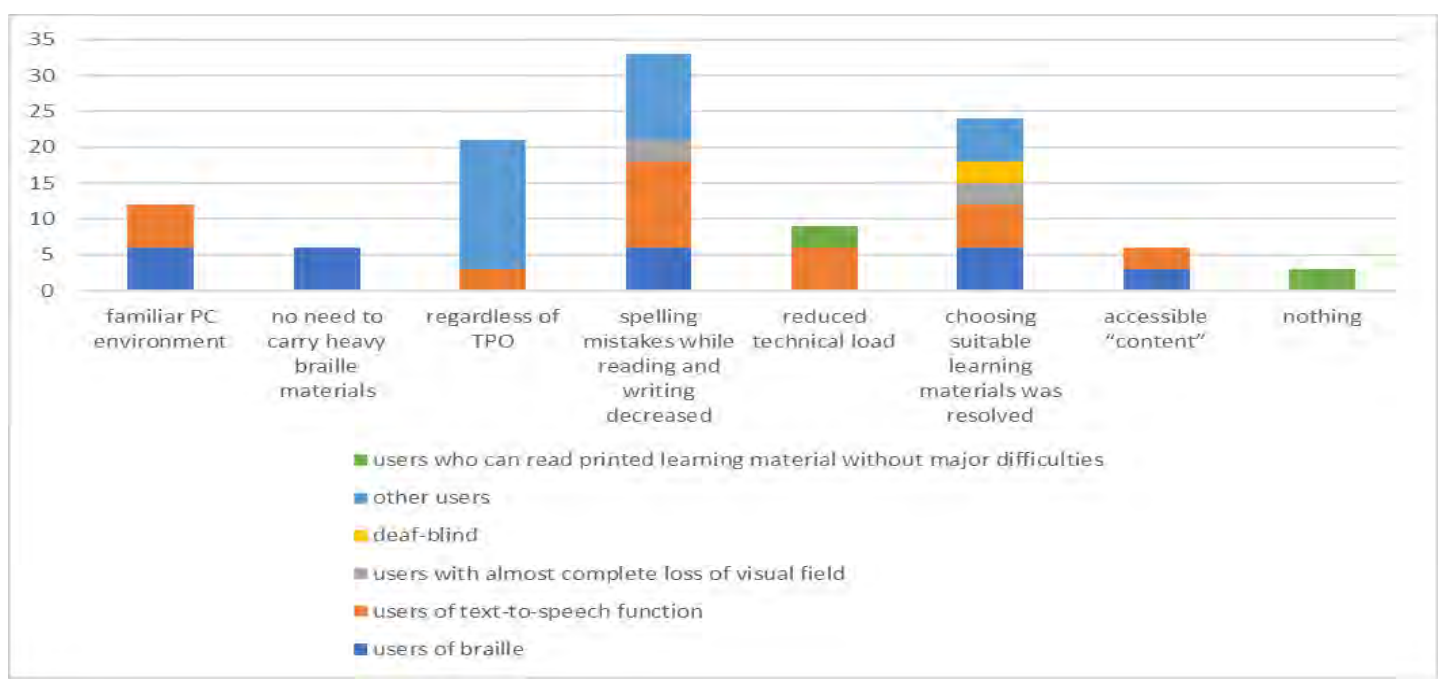

What it is worth mentioning is that students using braille and those who had no major visual difficulties commented that both could share the same learning material, enabling them to study together. This comment would lead to inclusive education, which has considerable significance for a future society that focuses on inclusivity and equity.

\section{Opportunities for further studies}

1) It is hoped that an additional longitudinal study can be carried out to discover whether the participants who have developed autonomic attitudes toward learning English and other subjects have become more confident about self-learning and retain this ability after graduating, as they build their careers.

2) It is hoped that this learning experience will enable visually impaired university students to understand their special needs fully and to ask for the consideration and support they need in inclusive educational situations and society. 


\section{References}

(2017b). Nihon no Kyouiku Assessment Gainenka ni Mukete (Sono2) — ERIC Database kara no originaruban $\lceil 20$ no Tobira $\rfloor$ no Katsuyou- [Towards conceptualization of Educational Assessment in Japan: utilization of original "the doors 20" list developed from ERIC database]. Tohoku Daigaku Daigakuin Kyouikugakukenkyuuka Kenkyunenpou volume 66 (1):199-208.

Abe, M. (2013). Kokusai Mubumento Kyouikuryouhougaku Kenkyusenta Kenkyu Ronbun. Chitekishougai wo Awaseyuusuru Shikakushogaiyouji no Gengo Shakaisei Skill Kakudai wo Mezashita Muubumento Kyouiku Purorugamu no Kaihatsu ni Kansuru Jissentekikenkyuu [Practicing Study on Development of the Movement Education Program for Visually Handicapped Infants with Intellectual Disabilities - Case Studies for Expansion of Movement Skills - ]. Jidoukenkyuu 92:19-31.

Arimoto, M. (2017a). Nihon no Kyouiku Assessment Gainenka ni Mukete (Sono1) — ERIC Database kara no originaruban $\lceil 20$ no Tobira $\rfloor$ no Katsuyou- [Towards conceptualization of Educational Assessment in Japan: utilization of original "the doors 20" list developed from ERIC database]. Tohoku Daigaku Daigakuin Kyouikugakukenkyuuka Kenkyunenpou volume 65 (2):125-151.

Hewett, R. (2018). Balancing inclusive design, adjustments and personal agency: progressive mutual accommodations and the experiences of university students with vision impairment in the United Kingdom, International Journal of Inclusive Education:1-18.

Hewett, R. (2019). Recruiting and Retaining Participants in a Longitudinal Qualitative Study. SAGE Publications Ltd:1-12.

Hewett, R., Douglas, G., McLinden, M., \& Keil, S. (2017). Developing an inclusive learning environment for students with visual impairment in higher education; progressive mutual accommodation and learner experiences in the United Kingdom. European Journal of Special Education, 32(1): 89-109.

Hunt, E. (2002). Approaches to Teaching English as a Foreign Language to the Visually Impaired. Estonian Institute of Humanities, Department of English.

Inagaki, K., Chikae, H., Koshimura, S., Nozaki, M., Kuribayashi, M., Wada, M. (2017). Chitekishogai Tokubetsusshiengakkou ni Okeru "Asobi no Shido" ni Kansuru Jissentekikenkyu: Muubumento Kyoikuryouhou no Shiten wo Irete [Practicing Study on "Lesson of Play" for Children with Intellectual Disabilities at the Special School: Utilize Movement Education and Therapy]. Kyoikujissenkenkyuu: Toyama Daigaku Ningenhattatsukagaku Kenkyuujissen Sougousenta Kiyou. (12):117-128.

Kashdan, S., Robby B., \& Cecilia E. W. (2005). Teaching English as a New Language to Visually Impaired and Blind ESL Students: Problems and Possibilities. American Foundation for the Blind.

Marek, B. (1999). A Blind Child in an English Language Classroom. A Journal for English Language Teacher Education, 2 (1):3-8.

Muto, D. (2013). Syogaiji ni Okeru Chiryokyouiku no Rekishitekiigi-Sandaya-chiryokyouikuin ni oite Sandaya Hikaru ga Nokoshita Fukushi / Hoiku Sisou-[Historical significance of "Chiryo-kyouiku" for children with disabilities : Welfare and childcare idea that Hiraku Sandaya has left Sandaya-chiryokyouikuin]. Nnagoya Management Junior College Kiyou, (54):59-69.

Radecki, J. (1984), Educational Therapy Defined. Journal of Learning Disabilities. Vol 17 issue 1:7.

Uchida,Y. (2018). Byooga no Hattatudankai ni Kansuru Ichikousatsu. Kyoikukagaku. Saitama Daigaku Kiyou Kyoikugakubu, 67(1) :29-41.

Wiazowski, J. (2000). Computers in Foreign Language Class of Visually Impaired Students, Visions and Strategies for the New Century. Proceedings of European Conference Cracow; Poland: 9-13, July 2000, International Council for Education of People with Visual Impairment. http://www.aetonline.org/

\footnotetext{
${ }^{i}$ Abe, M. (2013), Inagaki, K., Chikae, H., Koshimura, S., Nozaki, M., Kuribayashi, M., Wada, M. (2017),

Muto, D. (2013), Uchida,Y. (2018).

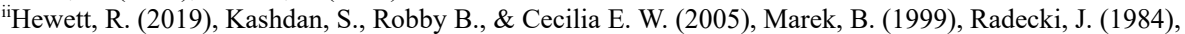

Wiazowski, J. (2000).

iii http://www.aetonline.org/

ivhttp://nild.org/

vhttp://www.aetonline.org/

${ }^{\text {vi }}$ Arimoto, M. (2017a), Arimoto, M. (2017b).
} 